\title{
Effects of Cattle on the Abundance and Composition of Carabid Beetles in Temperate Grasslands
}

\author{
Eleanor R. L. Bassett \\ Environmental Sciences, Thompson Rivers University, Kamloops, British Columbia, Canada
}

Lauchlan H Fraser

Department of Natural Resource Sciences and Biological Sciences, Thompson Rivers University

900 McGill Road, Kamloops, British Columbia, Canada V2C 5N3

Tel: 250-377-6135 E-mail: 1fraser@tru.ca

Received: October 16, 2014 Accepted: November 3, 2014

doi:10.5296/jas.v3i1.6731ＵRL: http://dx.doi.org/10.5296/jas.v3i1.6731

\begin{abstract}
Grasslands are of vital importance to the ranching industry. Cattle grazing can alter the structure and composition of the plant community, and may indirectly affect insect communities. We investigated the effects of cattle grazing and site productivity on carabid beetle abundance, dried weight (biomass), species richness and diversity. We used pitfall traps to capture beetles in three sessions in 2008 in Lac Du Bois Provincial Park, British Columbia (B.C.), Canada. To test for main and interacting effects of elevation and grazing, carabid beetles were quantified by trap for abundance, dried weight (biomass), species richness and Shannon's diversity. We found that elevation (a proxy of site productivity) was the most important predictor of carabid parameters, with lower elevation (low site productivity) having lower abundance, biomass, species richness and diversity compared to upper elevation (high site productivity). Although there was no main effect caused by grazing, there was a reduction in carabid biomass and diversity at grazed upper elevation sites compared to ungrazed upper elevation sites, suggesting that site productivity and plant structure affects carabid communities. Cattle management of natural grasslands benefits by considering biodiversity of all biota, including invertebrates. Carabid species diversity can be maximized by restricting grazing at high site productivity where plant biomass and litter is high.
\end{abstract}

Keywords: Carabidae, Cattle exclosure, Environmental gradient, Ground beetle, Range management 


\section{Introduction}

Half of the world's terrestrial land base is grazed by domesticated livestock (Havstad 2008), and grasslands represent an important and heavily managed ecosystem for cattle grazing. Grassland community structure and function can be altered by cattle grazing through removal of aboveground biomass, trampling of plants, and compaction of soil (Milchunas et al. 1988, Fleischner 1994, Olff \& Ritchie 1998). If cattle alter the structure and composition of the grassland plant community, how might this affect insect abundance and diversity?

An increase in plant structure, as measured by height and layering, has been positively correlated with insect diversity (Brose 2003). Higher vegetative productivity has also been shown to result in a more diverse invertebrate community (Kruess \& Tscharntke 2002, Patrick et al. 2008). Insects are sensitive to vegetation changes due to their requirements for oviposition sites, microsite preferences, hunting methods, and protection from predation (Eyre et al. 1996, Pöyry et al. 2006). Therefore, grazing and site productivity should influence insect diversity, at least indirectly, through plant community alteration.

Understanding patterns of grassland biodiversity is important because biodiversity can contribute to maintaining ecosystem function and ecosystem resilience (Kennedy et al. 2002). Carabid beetles (Coleoptera: Carabidae) are an important component of the trophic food web in grassland ecosystems (Fattorini et al. 1999, Pereira et al. 2002). Carabid beetles are often described as sensitive to disturbance and have therefore been used as bioindicators (Rainio \& Niemelä, 2003), or to rank environmental quality (Eyre et al., 1996, Zygmunt et al. 2006). While there is good understanding of the impacts of grazing on plant communities, contradictory results have been reported about grazing and site productivity effects on grassland carabid beetles diversity. Grazing has been shown to reduce (Cagnolo et al. 2002, Pöyry et al. 2006) or increase (Siemann 1998, Dennis et al. 2002) carabid diversity. Grandchamp et al. (2005) found that species richness of ground beetles was higher in mown plots compared to grazed in Swiss montane meadows and that fertilization was positively associated with carabid diversity in grazed meadows.

We examined the abundance, biomass, species richness, and diversity of carabid beetles along a natural grassland productivity gradient in sites open to and excluded from cattle grazing in southern interior temperate grasslands of British Columbia (BC), Canada. We tested the following hypotheses: 1 . The abundance, biomass, species richness and diversity of carabid beetles will be affected by grassland site productivity (based on changes along an elevation gradient). We predicted that carabid beetles will increase in abundance, biomass, species richness and diversity with site productivity. 2 . The abundance, dried weight, species richness and diversity of carabid beetles will be affected by cattle grazing. We predicted that cattle grazing will alter the structure and composition of the plant community, which, in turn, will reduce the abundance, biomass, species richness and diversity of carabid beetles. However, this effect will not be as strong at high productivity (elevation) sites compared to low productivity sites. In other words, there will be interacting effects on the beetle community between grazing and site productivity.

\section{Methods}




\subsection{Study Area}

Lac Du Bois (LDB) Provincial Park is 15000 ha and located northwest of Kamloops in south central British Columbia, Canada. The LDB park is a multi-use semi-arid grassland managed for cattle, recreation, and wildlife. There is an elevation change in LDB park from $350 \mathrm{~m}$ a.s.l. to $1100 \mathrm{~m}$ a.s.l. over a distance of approximately $10 \mathrm{~km}$. Elevation influences precipitation, ranging from $250 \mathrm{~mm} /$ year at lower elevations to $350 \mathrm{~mm} /$ year at upper elevations, which has established a gradient of plant productivity (van Ryswyk et al. 1966). The study sites at upper elevations have a soil organic carbon content of $\sim 150 \mathrm{~g} / 2 \mathrm{dm}^{3}$ and are dominated by rough fescue (Festuca campestris Rydb.) and Kentucky bluegrass (Poa pratensis L.). The study sites at lower elevations have a soil organic carbon content of approximately $40 \mathrm{~g} / 2 \mathrm{dm}^{3}$ and are dominated by big sagebrush (Artemisia tridentata Nutt.) and bluebunch wheatgrass (Pseudorogenaria spicata (Pursh) A. Löve) (van Ryswyk et al. 1966).

Grasslands in LDB park are grazed by cattle from April to November on a rest and rotation schedule at an Animal Unit Measurement of approximately one cow per hectare. Pastures grazed in the spring one year have been rested the second year, grazed in the fall the third year, and rested the fourth year on an ongoing cycle over the past four decades. A number of fenced cattle exclosures $100 \mathrm{~m}$ x $150 \mathrm{~m}$ exist within the park as reference sites to monitor changes in vegetation with the exclusion of cattle grazing. We selected four paired grazed and ungrazed sites, two at lower and two at upper elevations (Table 1), for a total of eight experimental sites.

Table 1. Elevation, grazing status, and coordinates of each transect.

\begin{tabular}{|c|c|c|c|}
\hline Site & $\begin{array}{l}\text { Grazed or } \\
\text { Ungrazed }\end{array}$ & $\begin{array}{l}\text { Elevation } \\
\text { (m) }\end{array}$ & $\begin{array}{c}\text { GPS } \\
\text { UTMs }\end{array}$ \\
\hline \multirow[t]{2}{*}{ Lower Grassland Site 1} & Ungrazed & 556 & $\begin{array}{c}10675164 \mathrm{E} \\
5623113 \mathrm{~N}\end{array}$ \\
\hline & Grazed & 434 & $\begin{array}{r}10676211 \mathrm{E} \\
5623795 \mathrm{~N}\end{array}$ \\
\hline \multirow[t]{2}{*}{ Lower Grassland Site 2} & Ungrazed & 584 & $\begin{array}{c}10667061 \mathrm{E} \\
5623795 \mathrm{~N}\end{array}$ \\
\hline & Grazed & 558 & $\begin{array}{c}10665673 \mathrm{E} \\
5625775 \mathrm{~N}\end{array}$ \\
\hline \multirow[t]{2}{*}{ Upper Grassland Site 3} & Ungrazed & 846 & $\begin{array}{c}10683648 \mathrm{E} \\
5630596 \mathrm{~N}\end{array}$ \\
\hline & Grazed & 882 & $\begin{array}{c}10684218 \mathrm{E} \\
5631037 \mathrm{~N}\end{array}$ \\
\hline \multirow[t]{2}{*}{ Upper Grassland Site 4} & Ungrazed & 917 & $\begin{array}{c}10680081 \mathrm{E} \\
5629098 \mathrm{~N}\end{array}$ \\
\hline & Grazed & 981 & $\begin{array}{c}10680990 \mathrm{E} \\
5631056 \mathrm{~N}\end{array}$ \\
\hline
\end{tabular}

\subsection{Vegetation Sampling}

Vegetation was sampled in July of 2008 at each of the eight sites. Daubenmire (1959) plant 
sampling method occurred along three parallel transects with 18 quadrats each for a total of 54 quadrats per site. Each transect was $14.3 \mathrm{~m}$ apart, and $71.5 \mathrm{~m}$ long. Four $1 \mathrm{~m}^{2}$ plots along the three parallel vegetation transects were randomly selected and clipped for above-ground litter and live standing biomass samples $(\mathrm{n}=12$ for each site). Biomass and litter were stored in brown paper bags and dried in a Yamato oven (Model No. DKN812) at $65^{\circ} \mathrm{C}$ for 48 hours and weighed with an analytical balance (Fisher Scientific accuseries 4102).

\subsection{Insect Sampling}

In July 2007 pitfall traps consisting of a dish (50 mm diameter, $30 \mathrm{~mm}$ depth) placed inside a cup (95 mm diameter, $97 \mathrm{~mm}$ depth) with a funnel were dug into the earth flush with ground level (Brose 2003). To allow for rainwater overflow, two small holes were cut into the bottom of each trap cup. These traps were arranged along a single $100 \mathrm{~m}$ transect per site, with one trap every $10 \mathrm{~m}$ with at least a $2 \mathrm{~m}$ buffer from any fence line. Plywood coverboards $(30 \mathrm{~cm} \times 30 \mathrm{~cm}$ $\mathrm{x} 4 \mathrm{~cm}$ ) were placed over each pitfall trap to reduce captures of Orthoptera and Diptera. In 2008, the traps were open for a period of seven days each in May, July, and August. Traps were replaced as needed. To set the trap, the small cup was filled with a liquid solution of $20 \mathrm{ml}$ propylene glycol (MSDS No. 9466107) and $20 \mathrm{ml}$ water (Grandchamp et al. 2005). Samples were collected in Whirl-Paks. Invertebrates were sorted, counted, then stored in $20 \mathrm{ml}$ disposable scintillation vials filled with denatured ethanol. Carabid beetle samples were sorted to species according to Lindroth (1969) "Carabids of Canada and Alaska". Sample specimens were labeled and pinned.

\subsection{Statistics and Analysis}

Visual estimates of percent cover were used to determine the dominant plant species. Plant species richness of each Daubenmire quadrat was used to find an average species richness by elevation. Analysis of variance (ANOVA) were performed on plant species richness by elevation. Kolmogorov-Smirnov and Shapiro-Wilk tests were used to check plant biomass, plant litter, and carabid dried weight distributions for normality. Plant litter weights were log-transformed to achieve normality. Plant species richness was log+1 transformed. ANOVA and post-hoc Tukey tests were performed on plant litter weight, plant biomass weight, and plant species richness to test for differences by elevation.

Although in some studies (Kromp 1990, Vanbergen et al. 2005) the numbers from pitfall traps were grouped per site to avoid the potential for pseudoreplication (Hurlbert 1984), many other studies treat pitfall traps as independent (e.g., Baars 1979, Desender \& Bosmans 1998, Baker \& Barumata 2006). In this study, the traps were placed far enough apart $(10 \mathrm{~m})$ to avoid differential trap catch (Baker \& Barmuta 2006), making it possible to treat each trap as independent.

Each individual carabid was dried for 48 hours at $65{ }^{\circ} \mathrm{C}$ in a Yamato oven (Model No. DKN812), and weighed using an analytical balance (Sartorius CP2P). Amara obesa's dried weights were log-transformed to achieve normality. Four two-way ANOVAs and post-hoc Tukey tests were performed on carabid abundance, carabid dried weight, carabid species richness and carabid diversity to test for differences by elevation and grazing. The 


\section{Macrothink}

Shannon-Weaver index was used to calculate carabid diversity (Shannon 1948).

\section{Results}

Upper elevation sites were dominated by rough fescue (Festuca campestris) (20\%), and Kentucky bluegrass (Poa pratensis) (14\%). Lower elevation sites were dominated by big sagebrush (Artemisia tridentata) (27\%) and bluebunch wheatgrass (Pseudorogenaria spicata) $(15 \%)$. Lower elevation plant communities produced less standing plant biomass and litter than upper elevation sites (Table 2; Fig. 1). Grazed sites had less live plant biomass and litter than exclosure sites (Table 2; Fig. 1). There was no interacting effect between grazing and elevation (Table 2), but the post-hoc Tukey test shows that the effect of grazing only reduced live plant biomass at lower elevation not upper elevation (Fig. 1 left). Plant litter was higher in exclosures compared to grazed sites at upper elevation, but no difference was found at low elevation (Fig. 1 right). Plant species richness was lower in the exclosures (Table 2) $\left(\mathrm{F}_{1,430}=\right.$ 26.7, $\mathrm{P}<0.001)$. Average plant species richness increased with elevation from a mean of 2.98 $(0.10)$ at lower elevation to $5.39(0.12)$ at upper elevation $\left(\mathrm{F}_{1,430}=227.8, \mathrm{P}<0.001\right)$.

Table 2. Separate and interacting effects of elevation (lower and upper) and grazing (grazed and exclosures) on plant live biomass and litter biomass per square meter. Bold numbers indicate significance at the $\mathrm{P}<0.05$ level.

\begin{tabular}{|l|r|r|r|r|}
\hline & \multicolumn{2}{|c|}{ Live biomass } & \multicolumn{2}{c|}{ Litter biomass } \\
\hline & \multicolumn{1}{|c|}{$\mathrm{F}$} & \multicolumn{1}{c|}{$\mathrm{P}$} & \multicolumn{1}{c|}{$\mathrm{F}$} & \multicolumn{1}{c|}{$\mathrm{P}$} \\
\hline Elevation & 127.902 & $<0.001$ & 22.786 & $<0.001$ \\
\hline Grazing & 16.664 & $<0.001$ & 6.263 & 0.014 \\
\hline Elevation $\times$ Grazing & 0.995 & 0.321 & 2.190 & 0.142 \\
\hline
\end{tabular}
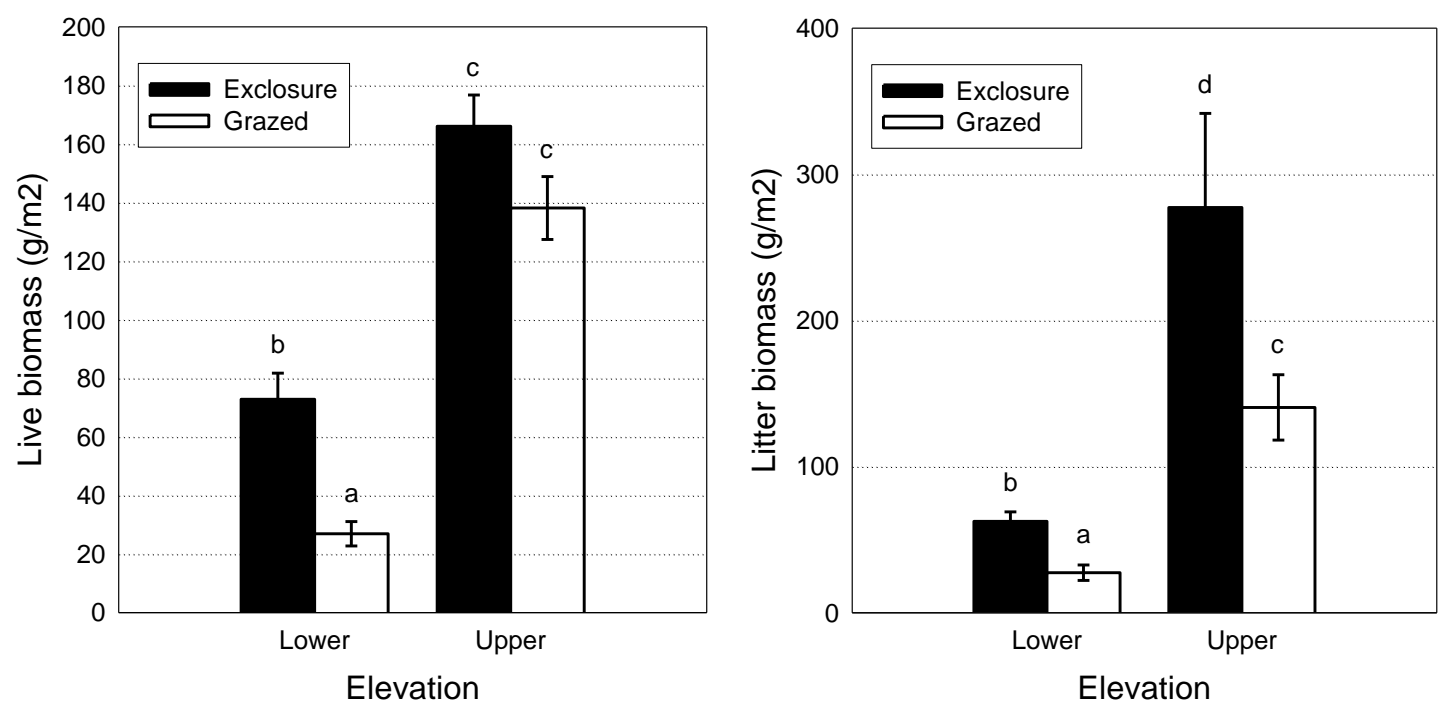

Figure 1. Mean dried plant biomass (left), and dried plant litter (right) at each elevation in grazed and exclosure (ungrazed) sites. Error bars represent standard error. Bars sharing the same letter are not significantly different using a post-hoc Tukey test.

Six species of carabids were identified (Fig. 2). Cymindis borealis and Calosoma moniliatum were the most 
abundant species. The majority of $C$. borealis were found in lower grasslands and the majority of $C$. moniliatum, and to a lesser extent Carabus taedatus, occurred in upper grasslands.

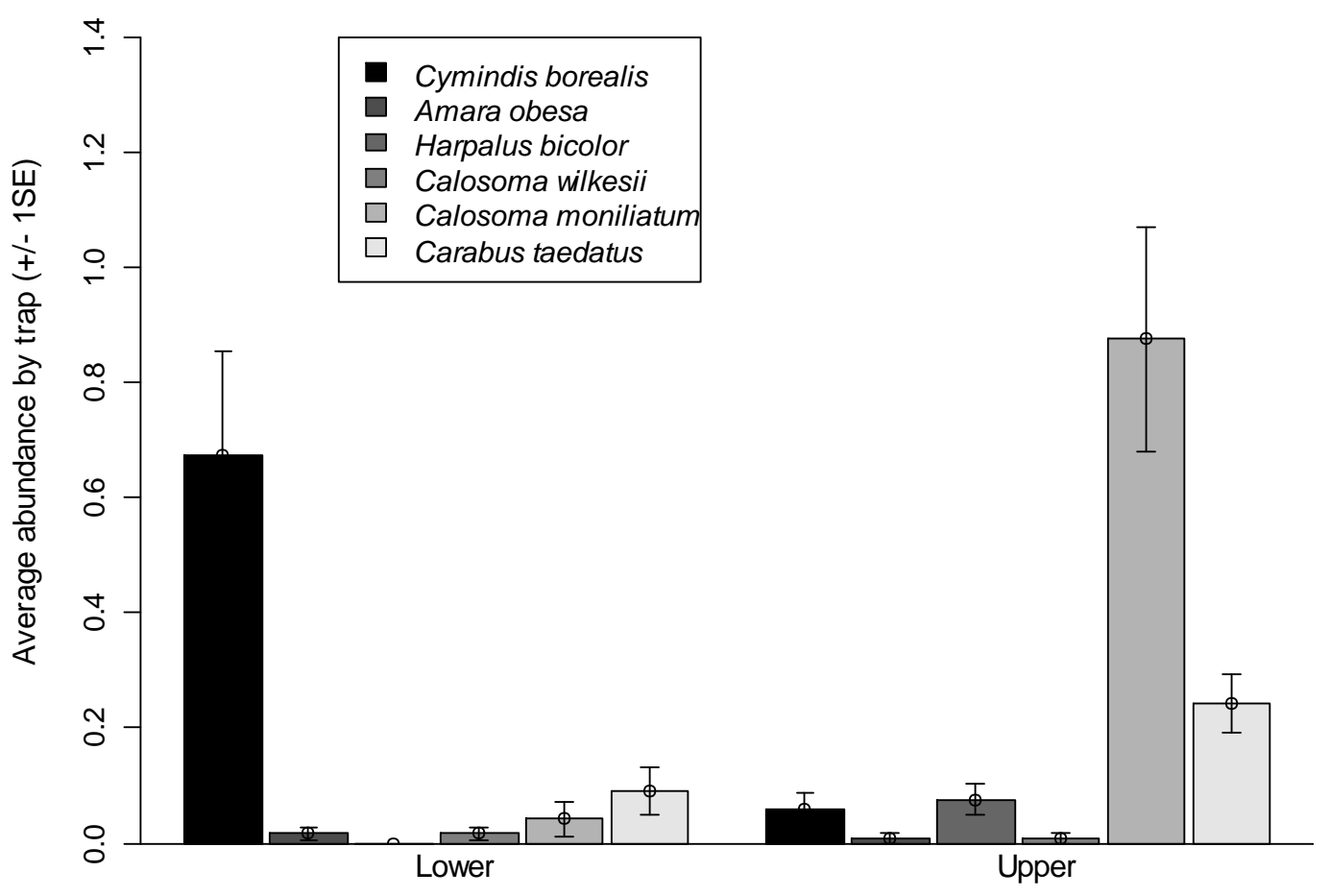

Elevation

Figure 2. Mean abundance of each carabid species, grouped by elevation. Species are ordered according to average body size (smallest to largest) from left to right. Error bars represent standard error.

Carabid abundance, biomass, species richness and species diversity were greater in the upper elevation sites (Table 3; Fig. 3). Grazing had no significant main effect at the $\mathrm{P}<0.10$ level on carabid abundance, biomass, species richness, or diversity (Table 3 ).

Table 3. Separate and interacting effects of elevation (lower and upper) and grazing (grazed and exclosures) on carabid beetle abundance, dried biomass, species richness, and Shannon diversity. Bold numbers indicate significance at the $\mathrm{P}<0.05$ level, $*$ indicate significance at the $\mathrm{P}<0.1$ level.

\begin{tabular}{|l|r|r|r|r|r|r|r|r|}
\hline \multirow{2}{*}{} & \multicolumn{2}{|c|}{ Abundance } & \multicolumn{2}{c|}{ Dry biomass } & \multicolumn{2}{c|}{ Species richness } & \multicolumn{2}{c|}{ Shannon diversity } \\
\cline { 2 - 10 } & $\mathrm{F}$ & $\mathrm{P}$ & $\mathrm{F}$ & $\mathrm{P}$ & $\mathrm{F}$ & $\mathrm{P}$ & $\mathrm{F}$ & $\mathrm{P}$ \\
\hline Elevation (E) & 15.475 & $<0.001$ & 19.973 & $<0.001$ & 28.996 & $<0.001$ & 7.939 & 0.005 \\
\hline Grazing (G) & 1.657 & 0.199 & 1.031 & 0.311 & 0.007 & 0.934 & 0.590 & 0.443 \\
\hline $\mathrm{E} \times \mathrm{G}$ & 0.063 & 0.803 & 2.935 & $0.088^{*}$ & 0.830 & 0.363 & 3.461 & $0.064 *$ \\
\hline
\end{tabular}

Carabid biomass and diversity had an interaction effect with elevation by grazing at the $\mathrm{P}<0.10$ level (Table 3 ). There was a lower biomass of carabids at upper elevation grassland exclosures compared to upper elevation grassland grazed sites (Fig. 3b). Diversity was also highest in exclosed upper grasslands compared to grazed upper grasslands (Fig. 3d). 


\section{Discussion}

We found that the abundance, dried weight (biomass), species richness and Shannon's diversity of carabid beetles increased with elevation (a proxy of site productivity), thus providing support for our first hypothesis. The increase we found in carabid abundance supports the findings of Siemann (1998) and Patrick et al. (2008) who showed that arthropod species richness and abundance were significantly higher in plots with greater plant productivity. The carabid species in our study were either xerophilous or described as preferring open and sandy soils with low vegetation (Lindroth 1969). All but one of the carabid species captured are known to be carnivorous as adults; the exception being Amara obesa, a species that is mainly herbivorous as an adult, and eats grasshopper eggs as a larva (Lindroth 1969). Insects can be regulated by plants (Ayal 1994), and will migrate to areas of high food availability (Bohan et al. 2000). Upper elevation sites produced more plant biomass, which possibly provided more food resources for the herbivorous adult $A$. obesa. More than eight times more individuals of $A$. obesa were captured in the higher elevation grasslands compared to the lower elevation. Harpalus bicolor and Carabus taedatus followed the same trend with elevation. One species, Cymindis borealis, did not follow this trend with elevation, possibly due to a difference in catchability, or a specific preference for the sandy soils and bare ground of lower elevations. Interestingly, $C$. borealis was the smallest of the six beetles in our study area. It is possible that the smaller sized beetle is better able to tolerate the hotter drier conditions in the lower grassland. Higher carabid abundance in upper elevations could be related to the increase in primary productivity and corresponding increase in food resource availability.

The hypothesis that abundance, dried weight, species richness and diversity of carabid beetles would be affected by cattle grazing was partially supported. Grazing was not a main effect, but there was an elevation by grazing interaction such that grazing reduced abundance and diversity, but only at upper grassland sites. The lower carabid diversity we found with grazing is inconsistent with Dennis et al. (2002) who found a higher diversity of arthropods in moderately grazed areas, and Crisp et al. (1998) who found high beetle diversity in modified (disturbed) habitats. Schmidt et al. (2012) found higher ant abundance and diversity in grazed sites but only at high productivity sites; ant abundance and diversity were reduced by grazing in low productivity sites. Cagnolo et al. (2002) determined that carabid diversity was reduced by heavy grazing in Argentinean montane grasslands. Since grazing in our study reduced plant biomass and plant litter it is reasonable to conclude that plant composition and structure likely affected beetle diversity and biomass. Perhaps the degree of grazing as a disturbance is important; therefore it is necessary to test a wide range of grazing intensities to better understand grazing effects on ground beetles.

We suspect that beetle parameters were not affected by grazing at lower elevation sites because plant live biomass and litter biomass in lower elevation sites was comparatively much lower than upper grasslands, even within exclosures. Such low levels of plant biomass would provide little cover or structure for beetle communities. 

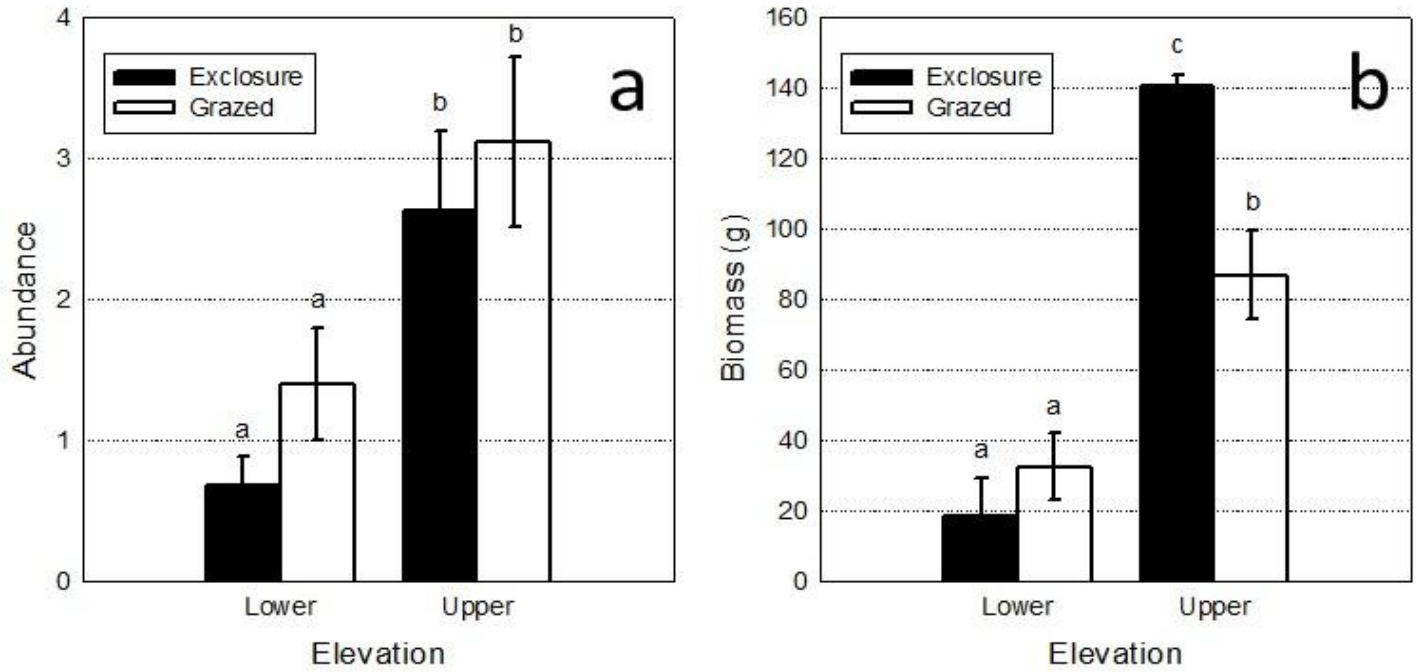

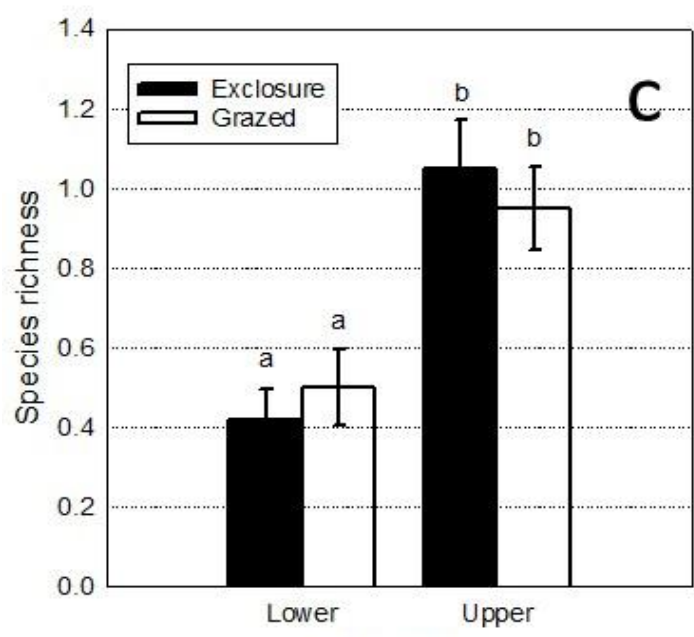

Elevation

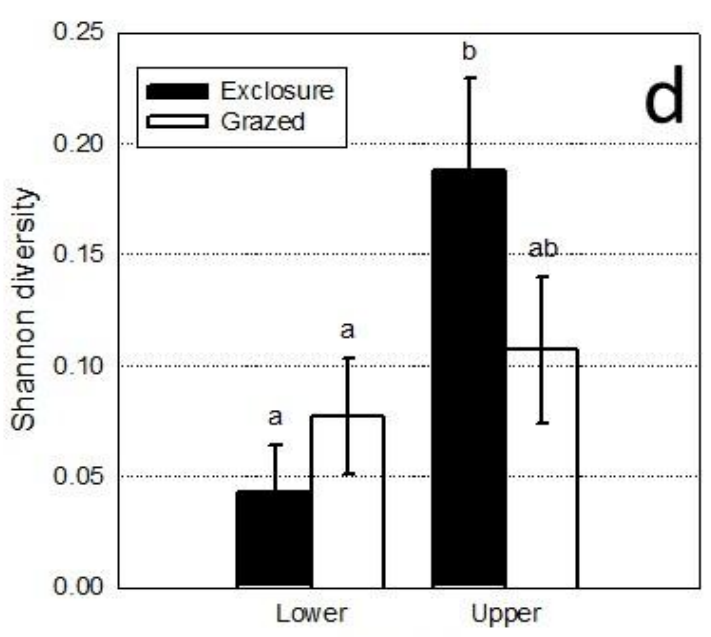

Elevation

Figure 3. Mean carabid abundance (a), biomass (b), species richness (c) and diversity (d) at each elevation in grazed and exclosure (ungrazed) sites. Error bars represent standard error.

Bars sharing the same letter are not significantly different using a post-hoc Tukey test.

It is perhaps not surprising to find changes in beetle communities within Lac Du Bois Provincial Park. Roughly et al. (2006) found differences in carabid beetle and spider assemblages within short geographic distances in the forest-aspen ecotone near Winnipeg, Manitoba. Carabids are sensitive to abiotic conditions (Judas et al. 2002). It is important to note that Lac Du Bois is topographically diverse, with large elevation changes over short distances, which create habitat mosaics that can influence invertebrate community responses (Engle et al. 2008). Elevation and the correlated changes in abiotic parameters seemed to affect ground beetle composition in the park. The occurrence of more diverse and abundant populations of carabids in upper elevations might support a more abundant and wider variety of bird and small mammal species. 


\section{Conclusion}

The conservation of dry grasslands and their carabid populations are important to regional biodiversity and conservation. Grasslands are an essential and continually used resource for ranchers, wildlife, and recreation. Since biodiversity conservation is an important component of grassland management plans and policy it is necessary to consider as many taxa as possible. Carabid abundance, diversity, and biomass change with site productivity along an elevation gradient and they can be affected by cattle grazing at high productivity sites. So while cattle grazing does not seem to affect carabid communities at low elevation, low productivity sites, they seem to negatively affect carabid communities at high elevation. To achieve a balance of grasslands conservation with the demands of cattle grazing and recreation, monitoring insect populations, specifically carabid beetles can be an indicator of site productivity and grazing intensity.

\section{Acknowledgement}

This work was funded by a Natural Sciences and Engineering Research Council (NSERC) of Canada Discovery Grant to L.H. Fraser and an NSERC Industrial Post Graduate Scholarship awarded to E. Bassett with the Grasslands Conservation Council of British Columbia (B.C.) as industry partners. We thank Cameron Carlyle, Amy Bitz, Jessica Gossling, Anna-Maria Pellet and Amanda Schmidt for their help in the field. We thank Agriculture and Agri-Foods Canada Kamloops Range Research branch for allowing use of cattle exclosures and the B.C. Ministry of Environment for allowing access to Lac du Bois Provincial Park.

\section{References}

Ayal, Y. (1994). Time-lags in insect response to plant productivity: significance for plant insect interactions in deserts. Ecological Entomology, 19, 207-214. http://dx.doi.org/10.1111/j.1365-2311.1994.tb00411.x

Baars, M. A. (1979). Catches in pitfall traps in relation to mean densities of carabid beetles. Oecologia, 74, 25-46. http://dx.doi.org/10.1007/BF00344835

Baker, S. C., \& Barmuta, L. A. (2006) Evaluating spatial autocorrelation and depletion in pitfall-trap studies of environmental gradients. Journal of Insect Conservation, 10, 269-276. http://dx.doi.org/10.1007/s10841-006-0016-8

Bohan, D., \& Bohan, A. C., Glen, D. M., Symondson, W. O. C., Wiltshire, C. W., \& Hughes, L. (2000). Spatial dynamics of predation by carabid beetles on slugs. Journal of Animal Ecology, 69, 367-379. http://dx.doi.org/10.1046/j.1365-2656.2000.00399.x

Brose, U. (2003). Bottom-up control of carabid beetle communities in early successional wetlands: mediated by vegetation structure or plant diversity? Oecologia, 135, 407-413.

Cagnolo, L., Molina, S. I., \& Valladares, G. R. (2002). Diversity and guild structure of insect assemblages under grazing and exclusion regimes in a montane grassland from Central Argentina. Biodiversity and Conservation, 11, 407-420. http://dx.doi.org/10.1023/A:1014861906082 
Crisp, P. H., Dickinson, K. J. M., \& Gibbs, G. W. (1998). Does native invertebrate diversity reflect native plant diversity? A case study from New Zealand and implications for $\begin{array}{llll}\text { conservation. } & \text { Biological } & \text { Conservation, } & 83,\end{array}$ http://dx.doi.org/10.1016/S0006-3207(97)00053-0

Daubenmire, R. (1959). A canopy-coverage method of vegetational analysis. Northwest Science, 33, 43-64.

Dennis, P., Aspinall, R. J., \& Gordon, I. J. (2002). Spatial distribution of upland beetles in relation to landform, vegetation, and grazing management. Basic and Applied Ecology, 3, 183-193. http://dx.doi.org/10.1078/1439-1791-00081

Desender, K., \& Bosmans, R. (1998). Ground beetles (Coleoptera, Carabidae) on set-aside fields in the Campine region and their importance for nature conservation in Flanders (Belgium). Biodiversity and Conservation, $7, \quad 1485-1493$. http://dx.doi.org/10.1023/A:1008813102410

Engle, D. M., Fuhlendorf, S. D., Roper, A., \& Leslie, Jr. D. M. (2008). Invertebrate community response to a shifting mosaic of habitat. Rangeland Ecology and Management, 61, 55-62. http://dx.doi.org/10.2111/06-149R2.1

Eyre, M. D., Lott, D. A., \& Garside, A. (1996). Assessing the potential for environmental monitoring using ground beetles (Coleoptera: Carabidae) with riverside and Scottish data. Annales Zoologici Fennici, 33, 157-163.

Fattorini, S., Manganaro, A., Piattella, E., \& Salvati, L. (1999). Role of the beetles in raptor diets from a Mediterranean urban area (Coleoptera). Fragmenta Entomologica, 31, 57-69.

Fleischner, T. L. (1994). Ecological costs of livestock grazing in Western North America. Conservation Biology, 8, 629-644. http://dx.doi.org/10.1046/j.1523-1739.1994.08030629.x

Grandchamp, A. C., Bergamini, A., Stofer, S., Niemelä, J., Duelli, P., \& Schidegger, C. (2005). Influence of grassland management on ground beetles (Carabidae, Coleoptera) in Swiss montane meadows. Agriculture, Ecosystems \& Environment, 110, 307-317. http://dx.doi.org/10.1016/j.agee.2005.04.018

Havstad, K. M. (2008). Mongolia's rangelands: is livestock production the key to the future? Frontiers in Ecology and the Environment, 6, 386-387. http://dx.doi.org/10.1890/1540-9295(2008)6[386:MRILPT]2.0.CO;2

Hurlbert, S. H. (1984). Pseudoreplication and the design of ecological field experiments. Ecological Monographs, 54, 187-211. http://dx.doi.org/10.2307/1942661

Judas, M., Dornieden, K., \& Strothmann, U. (2002). Distribution patterns of carabid beetle species at the landscape-level. Journal of Biogeography, 29, 491-508. http://dx.doi.org/10.1046/j.1365-2699.2002.00697.x

Kennedy, T. A., Naeem, S., Howe, K. M., Knops, J. M. H., Tilman, D., \& Reich, P. (2002). Biodiversity as a barrier to ecological invasion. Nature, 417, 636-638. 
http://dx.doi.org/10.1046/j.1365-2699.2002.00697.x

Kromp, B. (1990). Carabid beetles (Coloeptera, Carabidae) as bioindicators in biological and conventional farming in Austrian potato fields. Biology and Fertility of Soils, 9, 182-187. http://dx.doi.org/10.1007/BF00335805

Kruess, A., \& Tscharntke, T. (2002). Contrasting responses of plant and insect diversity to variation in grazing intensity. Biological Conservation, 106, 293-302. http://dx.doi.org/10.1016/S0006-3207(01)00255-5

Lindroth, C. H. (1969). The ground-beetles (Carabidae excl. Cicindelinae) of Canada and Alaska. Opuscula Entomologica Supplementum XXXV. Lund, Entomologiska Sallskapet. pp $1-1171$.

Milchunas, D. G., Sala, O. E., \& Lauenroth, W. K. (1988). A generalized model of the effects of grazing by large herbivores on grassland community structure. American Naturalist, 132, 87-106. http://dx.doi.org/10.1086/284839

Olff, H., \& Ritchie, M. E. (1998). Effects of herbivores on grassland plant diversity. Trends in Ecology and Environment, 13, 261-265. http://dx.doi.org/10.1016/S0169-5347(98)01364-0

Patrick, B. L., Fraser, L. H., \& Kershner, M. W. (2008). "Brown" world invertebrates contradict "green" world biodiversity theory. Research Letters in Ecology, vol. 2008, Article ID 694638, 4 pages, 2008. http://dx.doi.org/10.1155/2008/694638

Pereira, M. J. R., Rebelo, H., Rainho, A., \& Palmeirim, M. (2002). Prey selection by Myotis myotis (Vespertilionidae) in a Mediterranean region. Acta Chiropterologica, 4, 183-193. http://dx.doi.org/10.3161/001.004.0207

Pöyry, J., Luoto, M., Paukkunen, J., Pykälä, J., Raatikainen, K., \& Kuussaari, M. (2006). Different responses of plants and herbivore insects to a gradient of vegetation height: an indicator of the vertebrate grazing intensity and successional age. Oikos, 115, 401-412. http://dx.doi.org/10.1111/j.2006.0030-1299.15126.x

Rainio, J., \& Niemelä, J. (2003). Ground beetles (Coleoptera: Carabidae) as bioindicators. Biodiversity and Conservation, 12, 487-506. http://dx.doi.org/10.1023/A:1022412617568

Roughly, R. E., Pollock, D. A., \& Wade, D. J. (2006). Biodiversity of ground beetles (Coloeptera: Carabidae) and spiders (Araneae) across a tallgrass prarie - aspen forest ecotone in southern Manitoba. Canadian Entomologist, 138, 545-567. http://dx.doi.org/10.4039/n06-809

Van Ryswyk, A. L., McLean, A., \& Marchand, L. S. (1966). The climate, native vegetation, and soils of some grasslands at different elevations in British Columbia. Canadian Journal of Plant Science, 46, 35-50. http://dx.doi.org/10.4141/cjps66-005

Schmidt, A. C., Fraser, L. H., Carlyle, C. N., \& Bassett, E. R. L. (2012). Does cattle grazing affect ant abundance and diversity in temperate grasslands? Rangeland Ecology and Management, 65, 292-298. http://dx.doi.org/10.2111/REM-D-11-00100.1 
Siemann, E. (1998). Experimental tests of effects of plant productivity and diversity on $\begin{array}{lllll}\text { grassland } & \text { arthropod } \quad \text { diversity. } & \text { Ecology, } & \text { 79, } & \end{array}$ http://dx.doi.org/10.1890/0012-9658(1998)079[2057:ETOEOP]2.0.CO;2

Shannon, C. E. (1948). A mathematical theory of communication. Bell System Technical Journal, 27, 379-423, 623-656. http://dx.doi.org/10.1002/j.1538-7305.1948.tb00917.x

Vanbergen, A. J., Woodcock, B. A., Watt, A. D., \& Niemelä, J. (2005). Effect of land-use heterogeneity on carabid communities at the landscape scale. Ecography, 28, 3-26. http://dx.doi.org/10.1111/j.0906-7590.2005.03991.x

Zygmunt, P. M. S., Maryański, M., \& Laskowski, R. (2006). Body mass and caloric value of the ground beetle (Pterostichus oblongopunctatus) (Colopetera, Carabida) along a gradient of heavy metal pollution. Environmental Toxicology and Chemistry, 25, 2709-2714. http://dx.doi.org/10.1897/05-580R.1

\section{Copyright Disclaimer}

Copyright for this article is retained by the author(s), with first publication rights granted to the journal.

This is an open-access article distributed under the terms and conditions of the Creative Commons Attribution license (http://creativecommons.org/licenses/by/3.0/). 